\title{
Differential Recognition of the Serologically Defined HLA-A2 Antigen by Allogeneic Cytotoxic $\mathrm{T}$ Cells
}

\section{Population Studies}

\author{
Satoshi Horai ${ }^{1}$, Jan J. van der Poel ${ }^{2 *}$, and Els Goulmy ${ }^{2}$ \\ ${ }^{1}$ Department of Anthropology, Faculty of Science, The University of Tokyo, Tokyo, Japan \\ ${ }^{2}$ Department of Immunohaematology and Blood Bank, Unıversity Hospital, 2333 AA Leiden, the \\ Netherlands
}

\begin{abstract}
Human allormmune cytotoxic $T$ cells, sensitized selectively against the HLA-A2 antigen, were tested on a panel of selected target cells. Five HLA-A2 positive outlier cells could be identified. These outlier cells were only weakly lysed by HLA-A2 specific CTLs, although they were serologically indistinguishable from the other HLA-A2 positive, strongly lysed target cells. Furthermore, it was found that the outlier cells were poor cold target inhibitors in contrast to the other HLA-A2 positive target cells, which showed adequate inhibition of specific lysis of HLA-A2 positive target cells. Population studies indicate that the frequency of such HLA-A2 outlier cells may be approximately $10 \%$.
\end{abstract}

\section{Introduction}

It is generally accepted that gene products of the major histocompatibility complex (MHC) play an important role in cell mediated lympholysis (CML) both in the induction phase and in the recognition phase of allogeneic cytotoxic $T$ lymphocytes (CTLs). The antigens recognized by allogeneic CTLs were initially shown to be the serologically defined HLA-A, -B and -C antigens (Miggiano et al. 1972, Eijsvoogel et al. 1976, Grunnet et al. 1976), but also the HLA-D region products were proven to be target antigens (Mawas et al. 1975, Albrechtsen et al. 1979, Feighery and Stastny 1979, Johnsen 1980). Apart from the serologically defined antigens, CTLs were shown to recognize other determinants (Kristensen et al. 1974, Schapira and Jeannet 1974, Willumsen and Heron 1974, Sondel et al. 1975). One group of determinants recognized by allogeneic CTLs comprises the splits or subtypes of serologically defined antigens (Goulmy et al. 1976, Long et al. 1976, Bradley et al. 1978, Schendel et al. 1978, Kato et al. 1982) for which there is not always as yet a

\footnotetext{
* Address correspondence to J J van der Poel, Department of Immunohaematology and Blood Bank, University Hospital, Rijnsburgerweg 10, 2333 AA Leiden, the Netherlands
} 
serologically defined counterpart Biddison and co-workers (1980d) described an HLA-A2 variant, which by virus immune CTLs and an HLA-A2 restricted ant1-HYCTL (Goulmy et al 1982), was shown to be recognized differently from most other IILA-A2 positive cells Another possible HLA-A2 variant, detected by an HLA-A2 restricted antı-H-Y CTL, was recently described by Pfeffer and Thorsby (1982)

We ieport here the results of a systematic study on the occurrence of serologically HLA-A2 positive cells, which are not or only minımally lysed by alloummune HLA-A2 specific CTLs Approximately $10 \%$ of a randomly selected panel of HLA-A2 positive individuals could be identified as coutlier cells Furthermore, the outher cells can be divided into different subsets

\section{Materıals and Methods}

Coll dimers Call donors were selccicd from our files of HLA-A B, C and DR typed, healthy blood donors selution was enther perfoi med randomly or according to HLA phenotypes in order to obtaln C II s dilected iganst the scrologic illy defined HLA A2 antigen

CML ic imetuc CML was petformed according to the Luropean standard technique (f uropean CMLgioup repore III 1980) ln be ief induccr culturcs (1 e standard mixed lymphocyte cultures) were est Iblished for 6 dilys followed by CML testing $(4 \mathrm{~h})$ at four different $\mathrm{C}$ [L dilutions aganst $10^{4}{ }^{51} \mathrm{Cr}$ labeled PHA.stumulatul ( 3 days) lymphoblasts

Cold tarat inhbuson $\mathrm{T}$ be C ML mbubition capacity of selected cells was tested by addition of non- ${ }^{51} \mathrm{G}$ labeled (cold) PHA stimulated cells to the specific combination (c $\mathrm{g}$ effector $\mathrm{AB}$ aganst ${ }^{51} \mathrm{Cr}$ labeled targel culls B) A fixed numbur of cold targets $\left(10^{5}\right)$ was added $1010^{4}$ hot targets at different CTL/hot target cell I attos Control values were est ablsh hed by ldding cold competitors dutologous either to the responder or the stumul tior celk

Cakulaton of results Cytotoxicity wal calculated for each CTL/target ratto accordung to the formula (experimental spontaneous) $\mathrm{cpm}$

(maximum spontaneous) $\mathrm{cpm}^{-} \times 100=$ percent release

The uxpurumental results from difurunt expen iments were normalized to a percent relative cylotoxic rcsponse (percent RCR) b esed on the "pecific sesponse for a given CTL and calcul ted by the for mula

$$
\begin{aligned}
& \text { percent teledse of ixperimental target } \\
& \text { perccul rele isc of specific target }
\end{aligned}
$$

In all expermonts described the percent RCR wds calculated based on the pet cent rele sse obsci ved at a



Abrot mion of HLA A2 antseta IILA-A2 spectic anteserd were absorbed using $2 \times 10^{\text {ri }}$ cells per $\mathrm{ml}$ of surum tor 30 min at $100 \mathrm{~m}$ temperature Unstımulated puripheral blood lymphocy'es PHA stumulated lymphouylus ind I pstem Bart virus transformed cells were used for absorplions The absorbed antisera were testud on sclected cells in the Nationel lustitutes of licalth technique

\section{Results}

IILA-A2 specific CTLS fall to lyse some seroloqually defined HLA-A2 positwe iarget rells

In the experiments that initiated this study, it was noted that the percent lysis of an HLA-A2 specific CTL against three HLA-A2 positive target cells was margindl 
compared with the percent lysis aganst the specific target cells and most other HLA-A2 positive target cells Since this phenomenon was reproducible, an expanded panel of HLA-A2 positive target cells was subsequently studied using a number of allogeneic CTLs

Four different CTLs were generated aganst the HLA-A2 antigen between unrelated individuals The HLA-A, $-B,-C$ and $-D R$ genotypes of the responder and stımulator cells used and the percent lysis of each CTL against autologous and specific target are listed in Table 1 Cytotoxicity of the CTLs against the corresponding specific target cells 1 anged from $51-78 \%$ lysis at CTL to target ratio 401 Marginal cytotoxicity ranging from $0-4 \%$ lysis was observed against the corresponding autologous targets

The results of the panel study in which 58 HLA-A2 positive and $28 \mathrm{HLA}-\mathrm{A} 2$ negative target cells have been tested are presented in Figure 1 A clearcut bimodal distribution of positive and negative targets was observed As expected, all CTLS lysed most of the HLA-A2 positive target cells strongly ( $60 \% \mathrm{RCR}$ or more), while the HLA-A2 negative idrgets, wilh only a few exceptions, had RCR of $20 \%$ or less The three target cells mentioned above (designated LV1, LV2 and LV3) were recognized by all HI A-A.2 specific CTLs tested, $1 \mathrm{e}$, ds outher cells their RCR was well below $60 \%$ Furthermore, two ddditional outher cells (designated LV4 and LV5) were identified, which were consistently lysed less efficiently by two of the CTLs ( $\mathrm{e}$, CTL1 and 2) However, LV4 and LV5 were not recognized as outlier cells by CTL3 and 4

Inhibution of lysis by outler cold competitor cells

The HLA-A2 outlier cells were also tested as cold competitors for cytotoxicity agalnst "normal" HLA-A2 s' Cr-labeled target cells As shown for one HLA-A2 specific CTL in Figure 2, none of the outher cells was capable of inhibiting the specific lysis In this respect they behaved the same as cold competitors, which were

Table 1 HLA genotypes of responder stimulator combinalions and percent CML ag unst tutologous and specific target cells

\begin{tabular}{|c|c|c|c|c|c|c|c|c|c|c|}
\hline \multirow{2}{*}{$\begin{array}{l}\text { Leffector } \\
\text { cells }\end{array}$} & \multicolumn{4}{|c|}{ Responder cells } & \multicolumn{4}{|c|}{ Stımulator cells } & \multicolumn{2}{|l|}{ Percent lysis* } \\
\hline & & & & & & & & & Autologous ${ }^{t}$ & Specific \\
\hline \multirow[t]{2}{*}{ CTLI } & A. 3 & Bw35 & Cw4 & DR 1 & $\mathrm{~A} 2$ & B5 & $\mathrm{Cw} 2$ & DR4 & 4 & 78 \\
\hline & A11 & B5 & & DR4 & $\mathrm{A} 2$ & BS & CWA & DR7 & & \\
\hline \multirow[t]{2}{*}{$\mathrm{CTL} 2^{7}$} & A1 & B8 & & DR1 & At & B8 & & DR3 & 0 & 67 \\
\hline & $\Lambda 1$ & Bw44 & & DRw6 & $\mathrm{A} 2$ & B44 & Cw5 & DR3 & & \\
\hline \multirow[t]{2}{*}{$\mathrm{CTL}_{3}{ }^{+}$} & Al & $\mathrm{B8}$ & & DR 1 & Al & $\mathrm{B} 8$ & & DR 3 & 2 & 51 \\
\hline & $\mathrm{A} 25$ & $B 44$ & Cw5 & DR3 & $\mathrm{A} 2$ & $B 44$ & $\mathrm{Cw} 5$ & DR3 & & \\
\hline \multirow[t]{2}{*}{ CTL4 ${ }^{\ddagger}$} & A 1 & B8 & & DR 1 & $\mathrm{Al}$ & B8 & & DR3 & 3 & 56 \\
\hline & A25 & B44 & Cw5 & DR3 & $\mathrm{A} 2$ & B44 & & DR4 & & \\
\hline
\end{tabular}

* Percent lycis at effector to target rituo 401

+ Taget cells from responder cell donor (autologous) and stmul 1 tor rell donor (specilic)

${ }^{*}$ CTL2 and 3 were generated aganst the same stmulator cell while CTL 3 and 4 were the same responder cell drected aganst two different stmulator cells 
$\%$ RCR

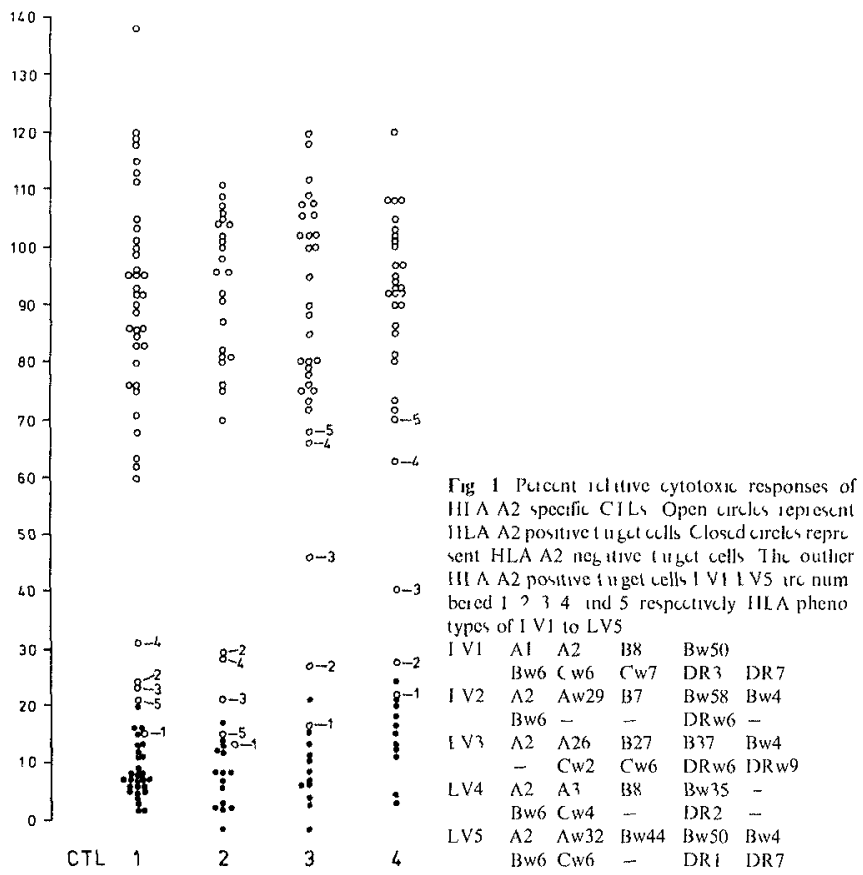

HLA-A2 negative or as the autologous cells On the other hand, all strongly lysed HLA-A2 positive target cells tested were able to block specific lysis although the amount of blocking showed some vallation

\section{Scroloqual couluaton}

Scrological andlysis using allommune serd with proven specificity for the IILA A2 antigen was purformed to confirm the presence of the IILA A2 antıgen on the five outiser cells and on 1 andomly chosen strongly lysed target cell, As expected, all cells carried the serologically defined HLA-A2 specificity As shown in Tabie 2 positivily in CML and the presence of the serological HLA A2 antigen werc highly assochated for all four CTLS $(p<00001$ by chi-square andlysis with Yates correction) 
Fig 2 Cold target mhibrion of an HLA A2 specific CTL CTL 1 was tested on specilic stumulator 1 irgel cells (target no 7) Cold target 12,34 , and 5 cori espond with the outher cells [ VI LVS whule cold iarget 6 und 8 ure two normal HLA $A 2$ positive lalget cells The percont lysis without addition of cold target cells is moduated by -

HLA plicnotypes cell 6

A2 Aw31 Bw38 Bw44

BW4 CW2 DR2 DRw6

III A phenotypes cell 8

A2 A3 BW62 -

Bw6 CW3 DR1 DRw6

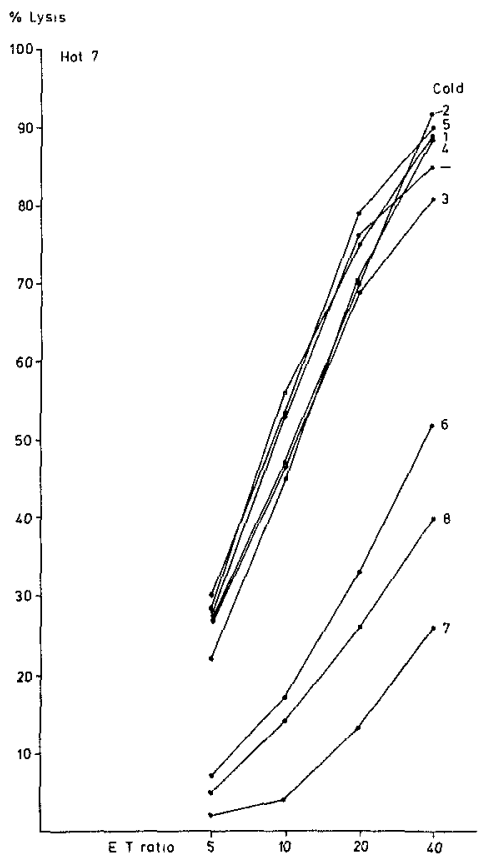

Iable 2 Correl tuon scrology and CML

\begin{tabular}{|c|c|c|c|c|c|c|c|}
\hline & \multicolumn{3}{|c|}{$\operatorname{IILA} \wedge 2^{*}$} & & \multicolumn{3}{|c|}{ HLA $\Lambda 2 *$} \\
\hline & & + & - & & & + & - \\
\hline $\mathrm{CML}^{+}$ & + & 53 & 0 & $\mathrm{CML}^{+}$ & + & 55 & 0 \\
\hline $\mathrm{ClL}_{2}$ & - & 5 & 28 & CTL34 & - & 3 & 28 \\
\hline
\end{tabular}

* The presence of the serologically defined HLA A2 antigen was tested with the allowntisela VR 46316 and VR 49484, which are ased as lyping sera in our department

1 Susceptibility of targat calls to lysis by CTLs duected aganst the HLA-A2 antigen

Two ser a were absorbed with three of the outher cells and three contu ol cells The results in Table 3 show that all HLA-A2 positive cells abson bed the anti-HLA-A2 activity One absorption was sufficient to remove the anti-HLA-A2 activity 
Table 3 Absorption of HLA A2 antiscr a by outler and control cells

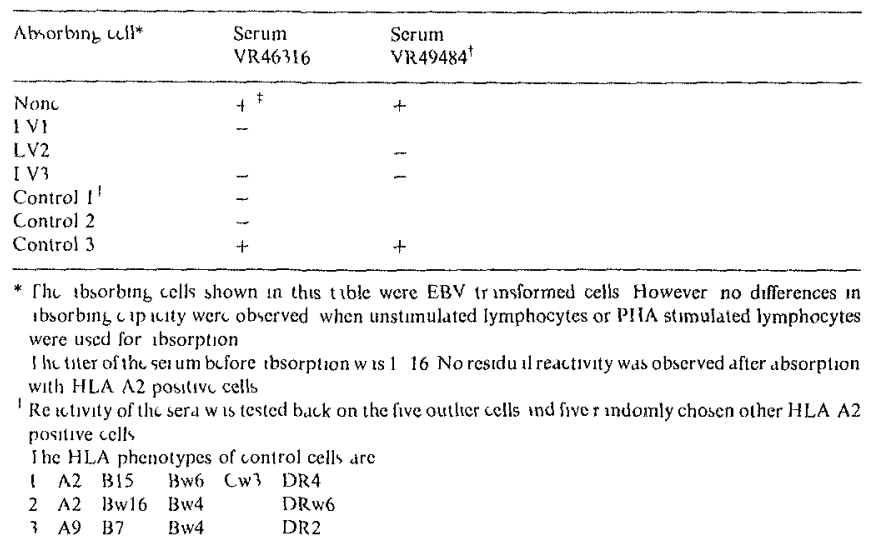

completely No differences in absorbing cupacity was observed between un stimulated peripheral blood lymphocytes PHA stimulated lymphocytes, and EBV transformed cells

\section{Discussion}

In this study evidence is presented that CTLs directed aganst the serologically defined HLA A2 antigen lysed the majority of HLA A2 positive target cells stiongly Howevor in a system itic study comprising a panel of 58 HLA A2 positive tirget cells five outlier cells were identified which were lysed consistently with low efficiency All outlier cells were positive for the HLA A2 antigen as analyzed with well defined allommune antisera specific for the A2 antigen When the outlies cells were tested as cold competitors, cytotoxicity dganst the specific target was hardly blocked if at all All other HLA A2 positive target cells could block the specific lysis Since the CTLs were highly specific for the serologically defined HLA A2 antigen the simplest interpretation is that the target antigen recognized by the cylotoxic $\mathrm{T}$ cells is the HLA A2 antigen itself Our data would then indicate that around $10 \%$ of the serologically defined HLA A2 antigens are variant or subtype

$A$ difference was observed in cytotoxic capacity between CTLS 1 and 2 as compared with CTLs 3 and 4 The latter CTLs lysed the outler cells LV4 and LV5 strongly (RCR above 60/) To clarify these differences in cytotoxic capacity severd possibilities can be considered First cytotoxic responses in bulk cultures dic polyclonal thus severd cytotoxic determinants might be recognized by clones pr escnt in the bulk population of CTLs tested Since responder and stimulator cells 
share HLA-A1, B8 and -B12 antigens, cytotoxic determinants associated with HLA B8 and -B12 (as described by Christiansen et al 1981 and Kato et al 1982) may play a role Interestingly, CTL2, which was generded against the same stimulator cell as CTL3, apparently did not recognze those extra specificities

Second, CTL 3 and CTL4 recognize differ ent epitopes of the HLA-A2 antigen as cytotoxic determinant, thereby defining a heterogeneity within a heterogeneity Preliminary results show that CTLs directed aganst the HLA-A2 antigens of the outher cells indeed subdivide HLA-A2 into at least three subtypes ( $\mathrm{J}$ van der Poel, $J$ Pool and E Goulmy, manuscript in preparation) Biddison and co-workers (1980b) documented chemical differences in the heavy polypeptide chain of an HLA-A2 variant that was detected by virus immune CTL Based on these observations, biochemical studies are in progress to document a molecular bists for the differentidl recognition of the HLA-A2 antigen using allogeneic CTLs as reagents

Population studies of CTLs between genotypically (Goulmy et al 1976) or phenotypically HLA identical individuals (Schapira and Jeannet 1974, Robinson et al 1978, Kato et al 1982) have demonstrated the existence of cytotoxic determinants that are seiologically indistinguishable Recently, Biddison and coworkers (1981) reported that virus immune CTLs recognized different epitopes of HLA-A 3 intigens in conjunction with different types of influenza virus Since five independent HLA A2 outler cells could be documented in this study, the same could hold tiue for the outher cells in an influenzd virus restricted system

The present study supports the notion that the polymorphism of HLA gene products is greater than anticipated The picture that arises for a number of HLA gene products resembles the complexity of target determinants described in mouse $I I-2-K$ mulants (Meleré et al 1980, Sherman 1981)

Finally, it seems of importance to document the influence of the variation of MHC antigens which is serologically indistinguishable but CTL distinguishable, on the occurrence of kidney graft rejection This may document the biological relevance of varidtions in MHC antigens in transplantation biology and infectious diseases, e g viral infections

As knowlddgmonts We thank Jos Pool und Rad Castelli Visser for thell cxcellent technical is astance and Ms $\Gamma H$ Noorderijk for plep uring the m inuscript This work wis in pi 1 supported by the Dutch Orbinisation for Heatlh Rese irch (TNO) the Dutch Foundation for Medic al Rese ir $h$ (FUNGO) which ss subsidived by the Dutch Organization for the Advancement of Pure Research (ZWO) and the I A Cohen Institute for Radiopathology and Radiation Protection (IRS)

\section{References}

Albtechtsen D Arnesen $C$ ind Thorsby E Cell medated lymphocytotoxir aty directed ag unst HLA D regron ploducts fiansplantation $27 \quad 338 \quad 341 \quad 1979$

Buddison $W r$ W ard I E Shearer $G_{3} M$ and Shaw $S$ The self determ in tnts recognized by hum in virus immune T cells $\mathrm{c}$ in be distinguished from the serologic ally defined HLA intigens $J$ immunot $124548-5521980$

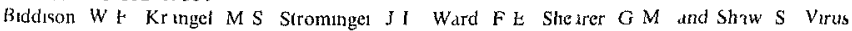
immune cytotoxic $T$ cells recognize structural differences betwcen serologically indisungussh tble HLA A2 molecules Hum Immunol 3 225-232 $1980 \mathrm{~b}$ 
Biddison, W E, Shearer, G M and Shaw, S Influenza virus-specific cytotoxic T cells are restricted by multiple HLA A3 related self antigens evidence for recognition of distinct self structures in conjunction with different foreign antigens $J$ Immunol 127 2231-2235, 1981

Bradley, B A, Goulmy, E, Schreuder, I, and yan Rood, J J Targets for kaller T cells in human lymphocyte differentiation Its application to cancer In B Serrou and C Rosenfeld (eds) INSERM SYMPOSIUM No 8, pp 231-240 Elsevier/North Holland Biomedical Press, Amsterdam, 1978

Christiansen, F T, Kim, S J, Silver, D M, and Dupont, B Cytotoxic effector cells against HLA antigens in strong linkage disequilıbrium identification of a strong, new CML determinant Hum Immunol 2 15-29, 1981

Eysvoogel, V P, Schellekens, P T A du Bols, M J G and Zeylemaker, W P Human cytotoxic lymphocytes after alloimmunization in vitro Tiansplant Rev 29 125-163, 1976

Feighery, C and Stastny, P HLA-D region associated determinants serve as targets for human cell mediated lympholysis $J$ Lxp Med $149 \quad 485-494,1979$

Goulmy, E, Termittelen, A, Bradley, B A, and van Rood, J J HLA restriction of non-HLA A, B, -C, and -D cell medidted lympholysis (CML) Tissue Antigens 8 317-326, 1976

Goulmy, E, van Leeuwen, A, Blokldnd, E van Rood, J J and Biddison, W E MHC restricted H-Y specific antibodıes and cytotoxic T lymphocytes can recognize different self determinants $J$ Exp Med 155, 1567-1572, 1982

Grunnet, N, Kristensen, T, and Kissmeyer-Nielsen, F Cell mediated lympholysis in man The impact of HLA-C antigens Tissue Antigens 7 301-309, 1976

Johnsen, H L Human B-blast specific target determinants in CML A methodological study $T_{\text {ISSue }}$ Antigens 15 189-198, 1980

Kato, S, Ivanyı, P , Lacko, E, Breur, B, du Bors, R, and Eysvoogel, V P Identification of human CML targets HLA B locus (B12) antigen variants defined by CTLs generated between B-locus-identical (B12) responder-stimulator pairs $J$ Immunol $128 \quad 949-955,1982$

Kristensen, T, Grunnet, N, and Kissmeyer-Nielsen, F Cell medidted lympholysı in man Occurrence of unexpected HLA-A (LA and Four) irrelevant lympholysis Tissue Antigens 4 378-382, 1974

Kristensen, T Human histocompatibility testing by T-cell mediated lympholysis A European standard CML technique Report from the European CML Study Group Ttssue Antigens 16 335-367, 1980

Long, M A, Handwerger, B S, Amos, D B, and Yunıs, E J The genetics of cell mediated lympholysis $J$ Immunol 117 2092-2099, 1976

Mawas, C, Charmot, D, and Sasportes, $M$ Is the LD region of the human MHC a CML target' In F Kissmeyer-Nielsen (ed) Histocompatibilty Testing 1975, pp 855-857, Munksgaard, Copenhagen, 1975

Melief, C J M de Wdal, L P, van der Meulen, M Y, Melvold, R W, and Kohn, H I Fine specificity of alloimmune cytotoxic $\mathrm{T}$ lymphocytes drrected against $\mathrm{H}-2 \mathrm{~K}$ A study with $\mathrm{K}^{\mathrm{b}}$ mutants $J$ Exp Med $151 \quad 993-1013,1980$

Miggidno, V C, Bernoco, D, Lightbody, J, Trınchierı, G B, and Ceppellinı, R Cell mediated lympholysis in vitro with normal lymphocytes as targets Specificity and cross-reactivity of the test Transplant Proc 4 231-237, 1972

Pfeffer, $\mathrm{P} F$ and Thorsby, E HLA-restricted cytotoxicity against male-specific (H-Y) antigen after dcute rejection of an HLA-1dentical sibling kidney Transplantation $33 \quad 52-56,1982$

Robinson, M A, Noreen H J, Amos, B A, and Yunıs, E J Target dntigens of cell mediated lympholysis discrimination of HLA subtypes by cytotoxic lymphocytes $J$ Immunol 121 14861490,1978

Schapıra, $M$ and Jeannet, $M$ Cell mediated lympholysis in HLA-A identical unrelated individuals Tissue Antigens 4 178-192, 1974

Schendel, D J, Wank, R, and Dupont, B Cell mediated lympholysis Examination of HLA genetıc fine structure and complementation using cytotoxic lymphocytes Eur J Immunol 8 634-640, 1978

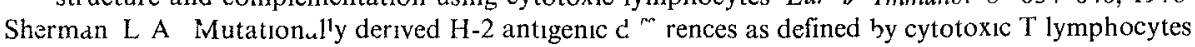
clones $J$ Immunol $127 \quad 1260-1269,1981$

Sondel, P M and Bach, F H Recognitive specificity of human cytotoxic T lymphocytes I Antigen specific inhibition of human cell-mediated lympholysis $J$ Exp Med 142 1339-1348, 1975

Willumsen, $\mathrm{J}$ and Heron, I Cell mediated lympholysis in man A case of "non-relevant" killing of third party persons Tissue Antigens 4 172-177, 1974

Recelved March 8,1982 ievised ver sion recewed May 10,1982 